DOI https://doi.org/10.30525/978-9934-26-114-5-42

\title{
РОЛЬ ІНФОРМАЦІЙНО-КОМУНІКАТИВНИХ TA SMART-ТЕХНОЛОГІЇ В СУЧАСНІЙ СИСТЕМІ ФІЗКУЛЬТУРНО-СПОРТИВНИХ ПОСЛУГ ДЛЯ ВІЙСЬКОВОСЛУЖБОВЦІВ ІЗ НАСЛІДКАМИ БОЙОВОї ТРАВМИ
}

\author{
Юденко О. В. \\ кандидат педагогічних наук, \\ викладач кафедри фізичного виховання, \\ спеціальної фізичної підготовки і спорту \\ Національний університет оборони Украӥни імені Івана Черняховського \\ Свириденко В. В. \\ Уповноважений Президента Украӥни \\ з питань реабілітації учасників бойових дій \\ Національна рада спортивної реабілітації захисників Украӥни \\ Юденко Ю. М. \\ Директор Центру навчання, здоров'я та розвитку «Мальва» \\ м. Київ, Украӥна
}

Актуальність. Сьогодні в світі більш поширеним в різних галузях життя стає використання інформаційно-комунікативних (IКТ) та SMART-технології. Сфера фізкультурно-спортивних послуг (ФСП) для військовослужбовців із наслідками бойової травми (БТ) не виключення, але дослідження свідчать про необхідність: 1) реалізації заходів, спрямованих на підвищення когнітивної компетенції учасників $\mathrm{ATO} / \mathrm{OOC}$ про особливості використання цих технологій в комплексній системі корекції здоров'я ветеранів та членів їх родин; 2) збільшення кількісної та якісної професійної підготовки / перепідготовки фахівців галузі ФКіС, які мають оптимальний рівень мотивації та відповідні компетентності для вирішення спеціальних завдань для подолання наслідків БТ.

Результати власних досліджень. Питаннями формування системи ФСП в Україні та реабілітації учасників бойових дій і членів їх родин; вивченням змін якості життєдіяльності учасників АТО/ООС в процесі залучення до системи надання сучасних ФСП та відновленням здоров'я ветеранів російсько-української війни присвячено роботи О.В. Юденко, О.В. Омельчук, А.С. Білоус, К.В. Винниченко, Н.М. Крушинської, 
О.В. Непомнящего, В.В. Свириденко (2021) [1; 3; 5]; О.О. Курбасова, C.O. Шапіро (2020) [2; 4] та ін.

Структура мотиваційної складової (мотиви, причини і обставини) спортивної та фізкультурно-оздоровчої діяльності у осіб 3 дисфункціями слуху та травматичними ураженнями OPA iз використанням Google-Форм та сучасних гаджетів, як оперативного i доступного інструментарію для збору інформації із використанням SMART та IКТ представлено О.В. Юденко, А.С. Білоус, С.В. Дьоміним та О. Зємічевим,. На думку багатьох фахівців галузі ФКіС, що суттєво полегшує роботу тренерів та учасників процесу споживання ФСП, зокрема в адаптивному спорті. Особливо ефективним використання означених IT-технологій отримання оперативної інформації виявилося вкрай важливим під час пандемії COVID-19. Відзначено, що зберігання даних в Google-Формах сприяє їх накопиченню, відслідковуванню окремих етапів контролю та оперативному реагуванню і внесенню відповідних коректив в оздоровчо-тренувальний процес. Тренериінструкторів наголошують на тому, що процес реалізації ФСП значно полегшує використання фітнес-браслетів, оксигенометрів та іншого обладнання, які поєднані із SMART-додатками в телефонах (puc. 1).

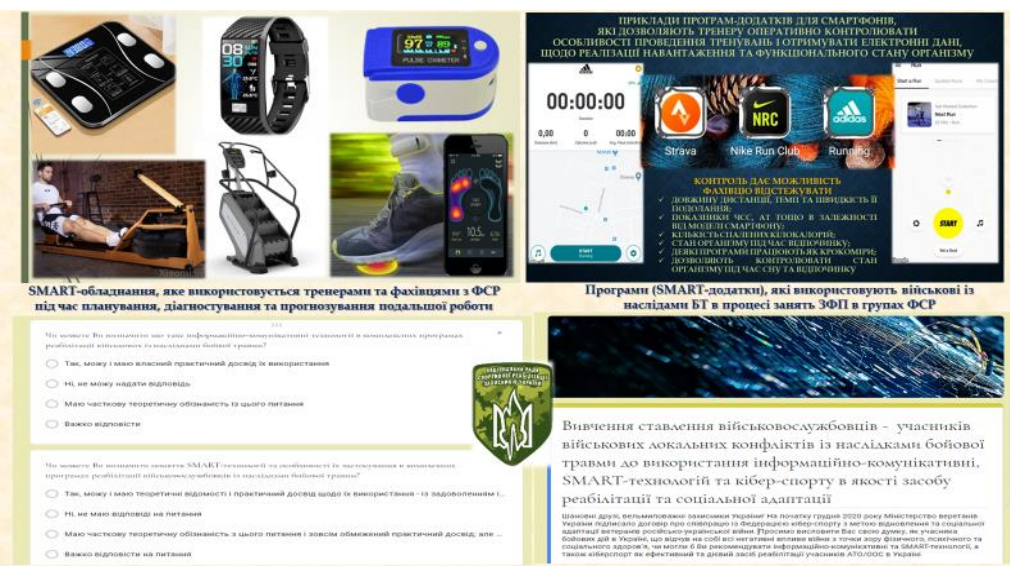

\section{Рис. 1 Сучасні SMART-технології, які використовуються в системі ФСП}

Збір інформації в регіональних осередках НРСРЗУ протягом 2018-2021 pp. здійснювався через Google-Форму (https://docs.google.com/forms/d/18A4Z-81_b5QY1TaIZQWj1OZz4eqL6jr9 
vINIYN8nMhI/edit; $\mathrm{N}=845$ осіб). Подано дані про рівень когнітивної компетенції військових із наслідками БТ щодо визначення основних дефініцій процесу надання їм сучасних ФСП; проявів негативних наслідків БТ на здоров'я; визначення їх ролі в системі споживання ФСП та реалізації програм ФСР (рuс. 1).

Дані опитування свідчать про те, що більш за все прояв наслідків БТ більш за все виявляється: у 97,51\% опитаних відзначають дисфункції різного ступеня тяжкості з боку психічного здоров'я (психо-емоційні розлади, нестабільна робота нервової системи, прояви ПТСР тощо); 90,89\% військових констатують розлади соціального здоров'я (порушення соціально-комунікативних зв'язків; проблеми у спілкуванні 3 друзями, рідними; відсутність розуміння; втрата роботи тощо); 84,11\% респондентів мають скарги на фізичне здоров'я; 30,53\% опитаних мають інвалідність внаслідок участі в бойових діях на Сході України. Отримані дані доводять, що 41,66\% військових можуть надати визначення поняття «ІКТ в системі ФСП осіб із наслідками БТ» i мають позитивний «власний практичний досвід їх використання», $48,52 \%$ осіб - мають часткову теоретичну обізнаність. Результати свідчать про те, що визначити поняття «SMART-технології» і виявити особливості їх застосування в системі надання комплексних ФСП ветеранам АТО/ООС із наслідками БТ можуть $66,27 \%$ респондентів i мають позитивний практичний досвід їх систематичного застосування у фізкультурно-оздоровчих заняттях. Отримані дані доводять, що $53,49 \%$ осіб можуть частково визначити роль та місце сучасних відеопрограм в комплексній системі сучасних ФСП військових із наслідками БТ; 21,54\% опитаних мають позитивний досвід їх застосування (рис. 2).

Ми розглядаємо «стресостійкість», як «комплекс особистісних якостей, що дозволяють переносити значні інтелектуальні, вольові та емоційні навантаження без особливих шкідливих наслідків для власного здоров'я, оточуючих і своєї професійної діяльності». ITтехнології використовуються в системі ФСП та у II половині процесу ФР після перенесеної БТ у шпиталях та санаторно-курортних закладах. Процес надання ФСП учасникам бойових дій із використанням засобів спортивних ігор, індивідуальних видів спорту, єдиноборств сприяє кількісній і якісній зміні показників Mental Health (депресивних станів, проявів ПТСР, підвищує рівень стресостійкості; сприяє вихованню самодисципліни, привчає відповідальності, вчить цінувати час; сприяє відновленню дрібної моторики, координації, розв'язанню логічних завдань тощо). 
International scientific and practical conference

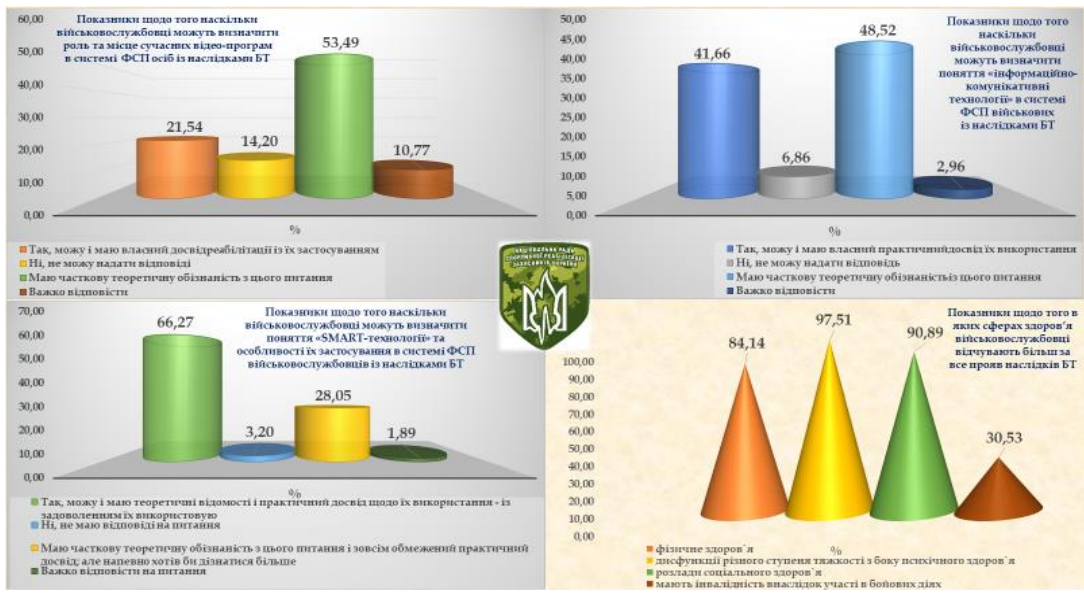

Рис. 2 Результати опитування щодо обізнаності військовослужбовців із наслідками БТ щодо визначення основних дефініцій дослідження

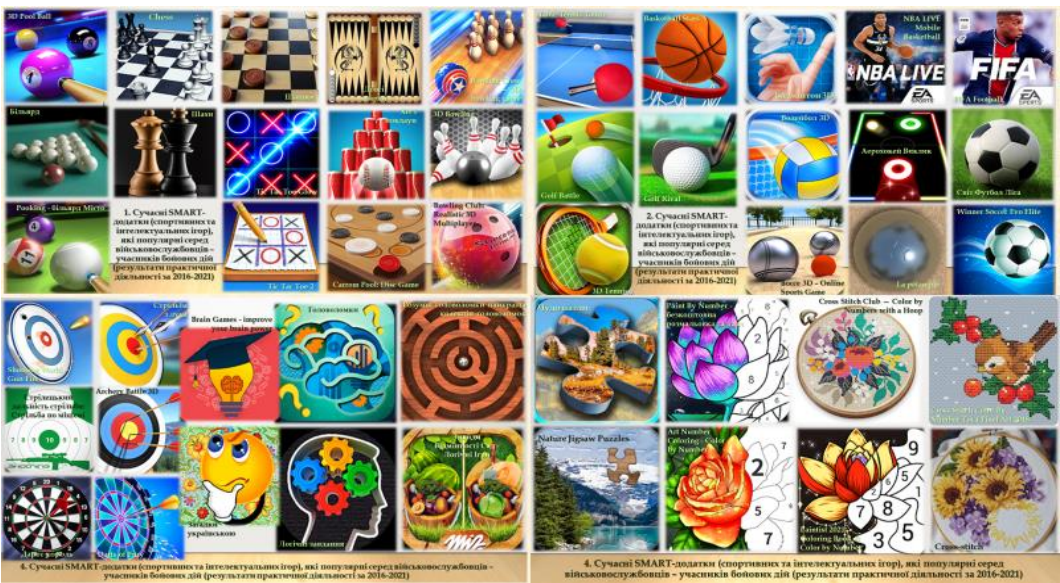

Рис. 3 Приклади SMART-додатків, які використовуються в комплексних програмах фізкультурно-спортивної реабілітації військовослужбовців із наслідками БТ

Висновки. Отже, в системі ФСП для військовослужбовців із наслідками БТ сучасні IKT-та SMART-технології (симулятори 168 
спортивних ігор; когнітивно-орієнтована терапія; relax-додатки для розвитку дрібної моторики, логіки тощо) відіграють важливу роль, особливо у II половині процесу фізичної реабілітації. Вважаємо необхідним подальшу реалізацію ФСП, спрямованих на корекцію та відновлення здоров'я серед більш широкого контингенту ветеранів АТО/ООС (включаючи жінок), які мають дисфункції та порушення внаслідок БТ.

\section{Література:}

1. Впровадження інноваційних фітнес-технологій в програми фізкультурно-спортивної реабілітації військовослужбовців із наслідками бойової травми (2021) / О.В. Юденко, Н.М. Крушинська, О.В. Омельчук. Науковий часопис НПУ імені М.П. Драгоманова. Серія № 15. Науково-педагогічні проблеми фізичної культури (фізична культура і спорт): зб. наук. працьь / За ред. О.В. Тимошенка. Київ : Вид-во НПУ імені М.П. Драгоманова, Вип.3 К(131)21. С. 445-451. (DOI 10.31392/NPU-nc.series 15.2021.3К(131).109)

2. Інноваційні засоби фізичної терапії та фізкультурно-спортивної реабілітації військових із дисфункціями в колінному суглобі внаслідок бойової травми (2020) / О. Курбасов, О. Юденко, Н. Крушинська. Abstracts of IX International Scientific and Practical Conference Stockholm, Sweden. C. 166-173.

3. Інноваційні засоби загальної фізичної підготовки військовослужбовців із наслідками бойової травми в системі фізкультурноспортивної реабілітації (2021) / О.В. Юденко, Н.М. Крушинська, O.В. Непомнящий, А.C. Білоус. The XXVI International Science Conference «Topical issues of practice and science», May 18-21, London, Great Britain. Pp. 500-507. DOI: 10.46299/ISG.2021.I.XXVI

4. Показники задоволеністю якістю життя у ветеранів АТО/OОС, 3 наслідками бойової травми, які займаються спортивними іграми (2020). О.В. Юденко, С.О. Шапіро, Ю.М. Юденко European scientific discussions. Abstracts of the 1st International scientific and practical conference. Potere della ragione Editore. Rome, Italy. C. 456-466.

5. Сучасна реабілітація учасників бойових дій та членів їх родин через відродження окремих фізкультурно-спортивних послуг (2021) / О.В. Юденко, В.В. Свириденко, К.В. Винниченко, Ю.М. Юденко, А.С. Білоус. Science, theory and practice. Abstracts of XXIX International Scientific and Practical Conference. Tokyo, Japan. June 08-11. Pp. 435-444. DOI: 10.46299/ISG.2021.I.XXIX. 